一論文一

（日本化学会誌，1989，（6), p. 961９66）

(C) 1989 The Chemical Society of Japan

\title{
種々の方法で調製したシリカアルミナゲルの細孔構造・ 酸特性および触媒活性
}

\author{
(1988 年 10 月 4 日受理)

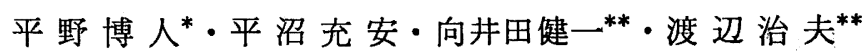

代表的固体酸触媒であり担体としてもよく用いられるシリカアルミナをケイ酸ナトリウムと硝酸アル ミニウムの水溶液から調製した。調製は，共ゲル化法を採用した。共ゲル生成反応における注入時間, 最終 $\mathrm{pH}$ 打よび混合方向の三つの操作因子に着目し， 7 種の触媒を調製した。かきませ速度は十分速い 条件で行ない, その他の条件は同一で行なった。収得ゲルの細孔構造, 化学組成, 固体酸性ならびに触 媒活性の测定を行ない，操作因子との関係を検討した。また，固体酸性と触媒活性との相関についても 検討した。

\section{1 緒言}

複合酸化物触媒の調製では，調製工程に括けるわずかな条件の 違いが, 構成粒子の粒子径, 化学組成, 表面特性に違いをもたら す。したがって，粒子の凝集（充填）がもたらす細孔構造や触媒 特性にも大きい違いが現われる。このよらに操作因子とバルク特 性ならびに表面特性との関連については調製工程の諸現象が絡み 合っているため未解明な点が多く，基礎的なデータの集積が待た れている”。

本研究では, シリカアルミナについて，共ゲル化法を採用し た。その調製条件として，アルミナ含有量を一定とすべく，反応 する二つの水溶液の濃度および体積比を一定とし共ゲルを調製 し, 注入時間, 混合方向ならびにゲル化後の $\mathrm{pH}$ 移動の三操作因 子に着目した。

共ゲル化法により調製されたシリカアルミナゲルについては,

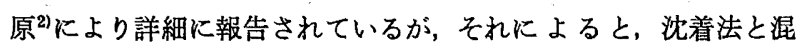
練法とは細孔構造も固体酸量もほとんど变わらないが，共ゲル化 法の場合これらにくらべて比表面積, 細孔容積の小さいものが得 られ，固体酸量も少ないとしている。アルミナ含有量が5から $25 \mathrm{wt} \%$ へと增大すると比表面積, 細孔容積はともに減少するこ とから，ゲルの形成時に Al の共存は大きい一次粒子を生成させ, かつ, これらの凝集度をむ大きくすると報告している。酸量の減 少については考察されていない。また,この報告では細孔棈造に 関しては比表面積と細孔容積についてしか取りあげられておら ず, 細孔径についての考察はなされていない。細孔容積は古くか ら細孔構造の特性因子としてょく用いられているが，アルミナ含 有量が変化する系列の試料を比較検討する場合に固体密度も同時

苫小牧工業高等専門学校工業化学科，059-12 苫小牧市

** 室闻工業大学化学工学科, 050 室蔺市

1）白崎高保, 藤堂尚之編, “触媒調製”, 满談社サイエンティ フィク（1974）p. 16; 太秦康光, 西村雅吉, 後藤克己, 触 媒学会編, “触媒工学詇座 5 , 触媒調製扣よび試験法”, 地 人韭館 (1967) p.1.

2）原穆，旭硝子研究報告，15，45(1965).
に変化してしまうので, 組成の異なる多孔体間の空間体積の割合 を比較するには細孔容積では不十分であり，空間率を用いるべき と考える。

本報告では試料組成をてルミナ含有量 $25 \mathrm{wt} \%$ になるような 水溶液の配合に限定し，前に述べたよらに調製条件の要因を三点 に絞り，この調製条件とゲル試料の細孔構造および化学組成, 固 体酸量, 触媒活性との関係, ならびに, これらの四つの相互関釈 について考察した。

\section{2 実 験 方 法}

\section{1 試料調製}

触媒調製のフローチャートを因 1 に示した。眓中の反応式は, シリカとフルミナの組成が变えられるよ5に水カラス (JIS 1 号 ケイ酸ナトリゥムに相当する和光純梖 1 級品, $\mathrm{SiO}_{2} / \mathrm{Na}_{2} \mathrm{O}$ モル 比 2.18 は分析値）と硝酸フルミニウムの量論関係に基ついた一 般式である。式中 $\mathrm{NaOH}$ は, 収得シリカアルミナ中のアルミナ 含有量が $20.6 \mathrm{wt} \%$ のとき $c=0$, これより大きいとき $c>0$, 小 さいとき $\mathrm{NaOH}$ の代わりに $\mathrm{HNO}_{8}$ を用いる。本研究で目標と するアルミナ含有量 $25 \mathrm{wt} \%$ の場合 $c / a=0.569$ となる。水 ガラス $1 \mathrm{~mol}(a=1)$ に対して硝酸アルミニウム $0.856 \mathrm{~mol}$, $\mathrm{NaOH} 0.569 \mathrm{~mol}$ となる。これを䀼度 $0.4 \mathrm{~mol} / l$ の水ガラス, 硝 酸アルミニウム，水酸化ナトリウムの水溶液としてゲル化反応に 供した。用いた液容量を表 1 の第二欗および第三闑に示す。第 1 の $\mathrm{A}$ 溶液の $340 \mathrm{ml}$ は, 水ガラス $215 \mathrm{ml}$ と水酸化ナトリウム 125 $\mathrm{m} l$ の混合水溶液 (以下 $\mathrm{Si}$ と略記する), $\mathrm{B}$ 溶液の $184 \mathrm{ml}$ は硝 酸アルミニウム水溶液（以下 $\mathrm{Al}$ と略記する）であり， $\mathrm{A}$ 溶液に 硝酸アルミニウム水溶夜 $(\mathrm{Al})$ を用いる場合は $245 \mathrm{ml}$ で, B溶 液の $450 \mathrm{ml}$ は, 水ガラス $286 \mathrm{ml}$ と水酸化ナトリウム $164 \mathrm{ml}$ の 合計值である。

ゲル化後, 一夜静膡, イオン交換水 $1 l$ による洗浄 (3回), $0.1 \mathrm{~mol} \cdot \mathrm{dm}^{-8}$ フンモ二フ水 $1 l$ による洗浄（1回), イオン交换 水 $1 l$ による洗浄（1 回）を行なった後, 沪過脱水したペースト 状ヒドロゲルを成型，乾燥 (室温)，500 $\mathrm{C} て ゙ 2$ 時間の辞成を娃て 


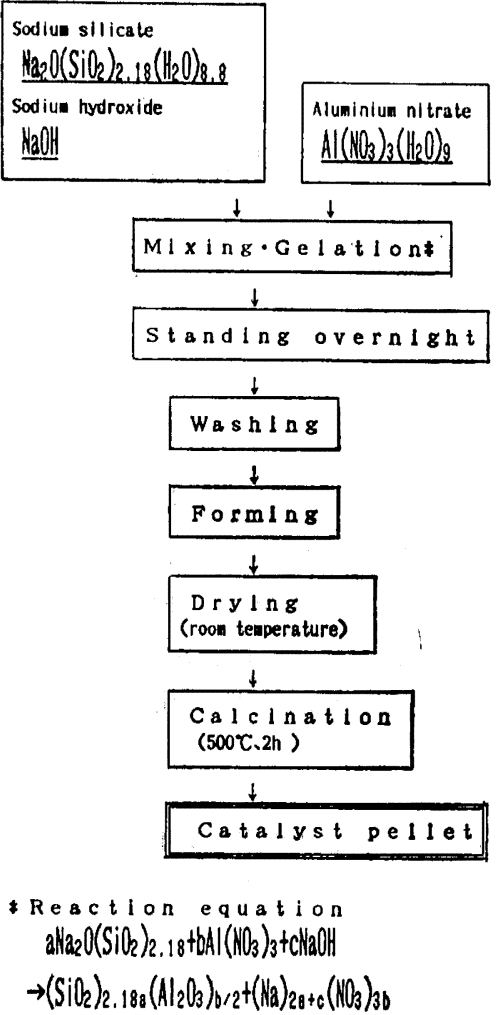

Fig. 1 Schematic diagram of catalyst preparation

シリカアルミナのキセロゲルペレットとした。

両水楁液の混合とゲル化においてはそれらの湠度, 侑碽比, 温 度ならびにかきま゙羽根の回枟速度を一定とした上で（1）注 入に要する淕問の長さ $(t),(2)$ ヒドロゲル生成直後の $\mathrm{pH}$ の 酸性侧あるいはフルカリ側への移怔，熟成，（3）混合方向（Si 海液を $\mathrm{Al}$ 溶液に加える畦合とその逆方向混合）などの影響を検 討した。ここに注入時战 $t$ とは，A溶液を、ミキサー中でかきま ぜられているB溶液に一定流昷で注入するのに要した胡間（秒）
でめる。

泥命・ゲル化に朋いるかきまぜ回分反応器として，2l容䅡の ガラスコップの底部に 150 r.p.s. のステンレススチール辪 4 收 羽根（先端鋭利な杉流型羽根）をるつ調理用ミキサー（ナショナ ル MX-150S 型)を用いた。

2.2 細孔權造・固体酸量・反活性および化学組成の測定

細孔梢造を代龙少る因子としての比表面積，空間确，細孔径分

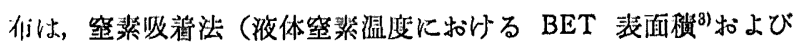
空潫の脱着等温線データの Cranston-Inkley 法 ${ }^{3141}$ に上る細孔径分 们）扣よび水銀圧入法8（水銀ポロシィーターによる細孔径分布，

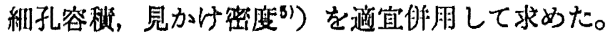

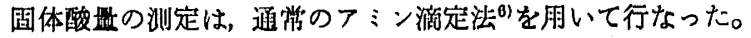
1-ブテンの與性化反応に関しては，固定眣流通反応器（内径 $10 \mathrm{~mm}$, キャリヤーガス水奖 $30 \sim 60 \mathrm{ml} / \mathrm{min}, 1$ 1ーブンンル分种 0.01〜0.02）により一次反忘としての反応速度定数を测定した。

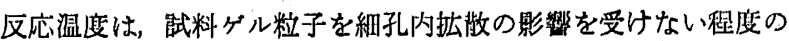
小粒子径 (100メッシュ以下) とした上で，外部扗䊀律速となら ない政四 $\left(180 \sim 210^{\circ} \mathrm{C}\right)$ とした。このことから, 反応温度 $190^{\circ} \mathrm{C}$ での反応速度定数をうらの触媒反応活性として用いた。分析は，ガ スクロマトクラフィー（FID, $\mathrm{Ar} キ ャ リ ヤ ー, ~ 30^{\circ} \mathrm{C}$, 分離カラ ムVZ-7，5 m) とよって行なった。

陚料位媒の失組成は，监北X線分析で湘定した。

\section{3 英験結果および考䕓}

\section{1 铜製条件と細孔構造, 化学組成}

各試料の混合・ダル化条件と得られたゲルの級孔情造因子を处 1 に，また細孔径分布を図 2〜4 に示した。これらの結果から， 共ゲル化反応に括ける混合の条件によって，細孔径分布に顕著な 变化が㲘められることがわかった。縕孔径分枊は，梢成粒子の粒

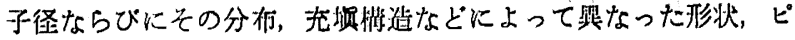
一ク位僻を示ず。ゲル佩製過程に将いて収得ゲルの粒子径, 細孔 情造，組成などの性状に影響を与えると考えられる因子"1 は 1)

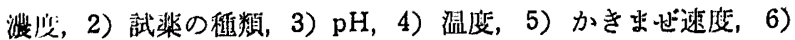
注入速吸，7）混合方向，8）㠿存イオン，9）嵝成温度，10）烧成

Table 1 Preparation condition, structural characteristics, and composition for the silica alumina gels

\begin{tabular}{|c|c|c|c|c|c|c|c|c|c|c|}
\hline Sample & $\begin{array}{c}\text { A- } \\
\text { solution } \\
(\mathrm{m} l)\end{array}$ & $\begin{array}{c}\text { B- } \\
\text { solution } \\
(\mathrm{m} l)\end{array}$ & $\begin{array}{c}\text { Pour time } \\
\text { of } A \text { into } B \\
t \\
\text { (s) }\end{array}$ & $\begin{array}{c}\text { Final } \\
\mathrm{pH} \\
(-)\end{array}$ & $\begin{array}{c}\text { BET specific } \\
\text { surface area } \\
S_{\mathrm{m}}^{a)} \\
\left(\mathrm{m}^{2} \cdot \mathrm{g}^{-1}\right)\end{array}$ & $\begin{array}{c}\text { Pore } \\
\text { size } \\
a_{\text {mod }}^{a)} \\
(\mathrm{nm})\end{array}$ & $\begin{array}{c}\mathrm{Al}_{2} \mathrm{O}_{3} \\
\text { content } \\
\mathrm{Ca}^{(d)} \\
(\%) \\
\end{array}$ & $\begin{array}{c}\text { Apparent } \\
\text { density } \\
\rho_{\mathrm{a}}^{b)} \\
\left(\mathrm{g} \cdot \mathrm{cm}^{-3}\right)\end{array}$ & $\begin{array}{c}\text { True } \\
\text { density } \\
\rho_{\mathrm{t}}^{c)} \\
\left(\mathrm{g} \cdot \mathrm{cm}^{-3}\right)\end{array}$ & $\begin{array}{c}\text { Porosity } \\
e^{c)} \\
(-)\end{array}$ \\
\hline $\mathrm{SA-1}$ & $340 \mathrm{Si}$ & $184 \mathrm{Al}$ & 1 & 4.50 & 186.2 & 9 & 30.8 & 1. 221 & 2.539 & 0.519 \\
\hline $\mathbf{S A - 2}$ & $340 \mathrm{Si}$ & $184 \mathrm{Al}$ & 31 & 4.50 & 166.2 & 14 & 31.9 & 1.028 & 2. 551 & 0.597 \\
\hline SA-3 & $340 \mathrm{Si}$ & $184 \mathrm{Al}$ & 4200 & 4.50 & 103. 9 & 24 & 35.2 & 0.919 & 2.587 & 0.645 \\
\hline $\mathrm{SA}-4$ & $340 \mathrm{Si}$ & $184 \mathrm{Al}$ & 1 & 3.68 & 155.6 & 17 & 23.7 & 0.987 & 2.461 & 0.599 \\
\hline SA-5 & $340 \mathrm{Si}$ & $184 \mathrm{Al}$ & 1 & 6.72 & 182.2 & 6 & 34.7 & 1. 469 & 2.582 & 0.431 \\
\hline SA-6 & $245 \mathrm{Al}$ & $450 \mathrm{Si}$ & 1 & 4.50 & 192.6 & 10 & 31.6 & 1.205 & 2.548 & 0.527 \\
\hline SA-7 & $245 \mathrm{Al}$ & $450 \mathrm{Si}$ & 1680 & 4.50 & 224.0 & 4 & 30.2 & 1.226 & 2.532 & 0.516 \\
\hline
\end{tabular}

a) Obtained from nitrogen adsorption.

b) Obtained from mercury porosimetry.

c) Obtained from calculation.

d) Obtained from fluorescent X-ray spectrometry.

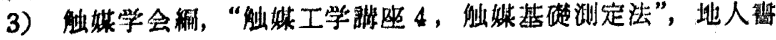
解 (1967) p. 50

4) R. W. Cranston, F. A. Inkley, Adv. Catal., 9, 143 (1957).

5) K. Mukaida, Powder Technology, 29, 99(1981).

6) 松崎五三男, 福田安男, 小林竝期, 久保浩一, 田部浩三, 似跌, 11，210(1969）；O. Johnson, J.Phys. Chem., 59, 827 (1955). 


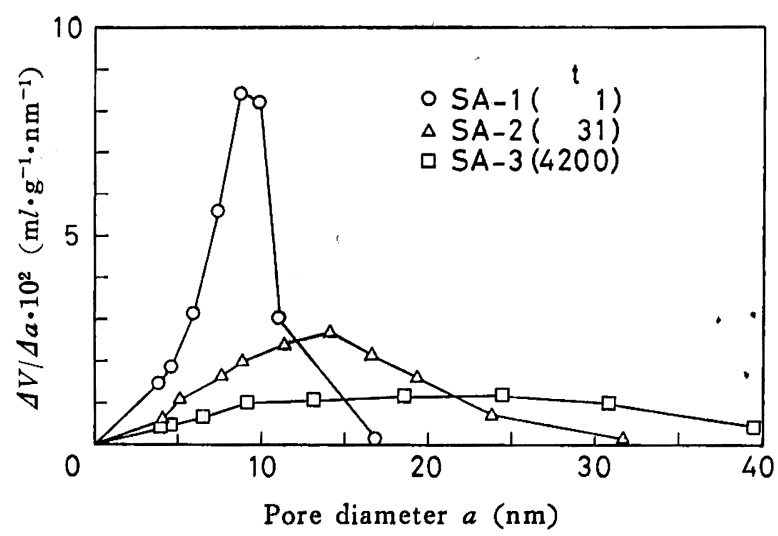

Fig. 2 Effect of the pour time on the pore size distribution

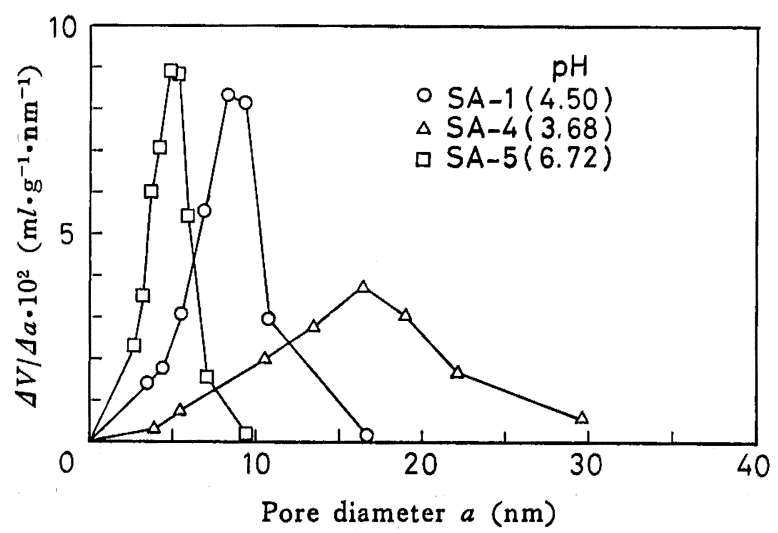

Fig. 3 Effect of the final $\mathrm{pH}$ on the pore size distribution

郝間などであるとされている。これら諸因子の中でとくに混合過 程に着目し 3），6，7）の項目を取り上げた。1)，2），4），5）, 9)，10）の項目は同一条件にした。

つぎにこれら三項目の特性因子に関して教察する。

\section{（1）注入時間（注入速度）と混合方向の影羿}

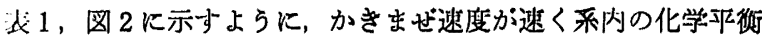

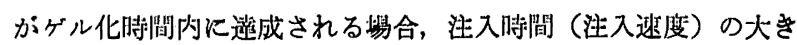
く舆なる SA-1，2，3 の間には，比装面稆，縕孔径分布，化学組 成招よび見かけ樒度の実測值に明らかな变化がみられる。 SA-1

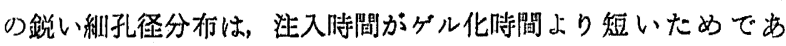
る。一位均一過飽和溶液ができ，その後に全成分が一度に固相に 䉼出ずるため，ゲル樦成粒子の粒子径は揃い，したがってそれら 粒于の光项空腺も揃って，敛い分布をもつにいたったものと考え られる。比裴面䄳も一度に生成した小粒子のため，大きい方に剭 する。これにくらべて, SA-3 は，注入郝間が長く後から入った ゲル化剤（B溶液， Al）による固相析出が，すでに生成している ゲル粒子上に不均一に起こって大粒子ができること，艮洔间にわ

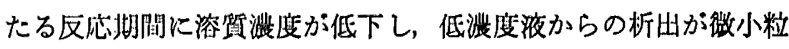
子を生成することなどにより粒子径分厉はきわめて厇くなる。そ の結果, 細孔径分布も広くなったと教えられる。

以上の現象を総括すると， SA-1 から3へと注入㽗間が艮くな

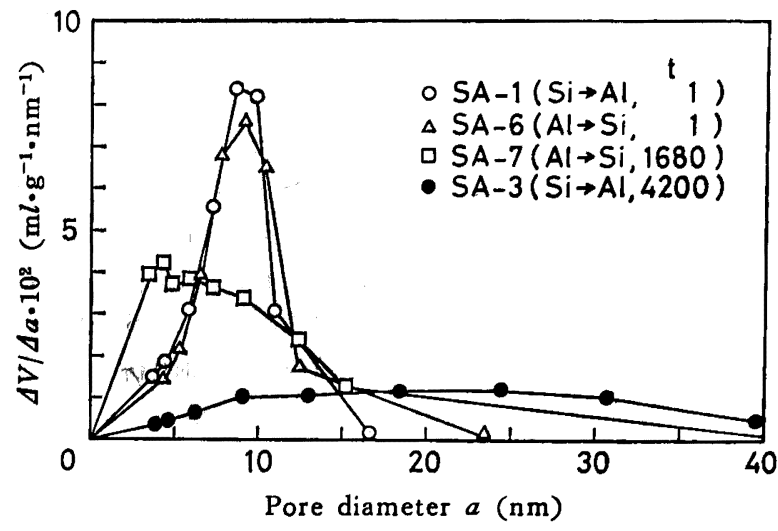

Fig. 4 Effect of the adding direction and the pour time on the pore size distribution

るにつれて比表面科は減少した。細孔径分布は幅広へ移行すると 同特にモード細孔径は増加し，見かけ密度は娍少，フルミナ含量 は增大しいずれも目標值 (25 wt\%) を大きく上回った。緒寻に述 べたよらに細孔構造の特性を評価するのに空間率を $\varepsilon=1-(\rho a)$ $\rho t)$ から水めると, 注入時間が長くなるにつれて增加しているこ とがわかった。

注入時間がゲル化時間より短い場合の SA-6 は比表面䖽，見か

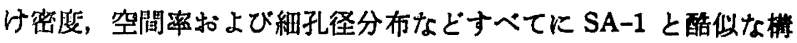
造を示し，混合方向による影整はみられなかった。注入時間が長 くなり一部のゲル化が先行する掦合の SA-7 では，此表面榬が増 大して拈り，平均粒子径が減少することを示している。このた め，細孔径分板は，モード径が小さい方へ移䎲した。また，見か け密度は增大し, 空問率は減少した。アルミナ含旦は減少した。 これらはSA-1 と SA-2 または SA-3 との咸係と逆であり, 混 合方向の違いを反咉していると思われる。

均一過飽和溶液からのゲル化洔間については, シリカについて の碓究”が多い。シリカのモノマーがポリマー（一次粒子）を形 成し二次元凝㷛, 三次元凝集（何れもシロキ甘ン結合-Si-O-Siによる)によりゲル化するので, $\mathrm{Si}^{4+}$ の濃度, $\mathrm{pH}$, 温度などの 影細が大きく，数秒から数百時間へと幅が厇い。シリカフルミナ のような二成分系の掦合の報告はみられないか，本実験で SA-1 または6での視察による結果では 3〜4 秒であった。

\section{（2）最終 pH の移勤による影㔀}

装 1 でわかるよらに, SA-1〜3 および 6,7では一定分年比の 溶液を加え合わせたので，注入壯間に関係なく垠終 $\mathrm{pH}$ は 4.5 であった。坄終 $\mathrm{pH}$ の影整を調へるために SA-1 のゲル化完了 後，硝酸または $\mathrm{NaOH}$ を添加して，その $\mathrm{pH}$ をントさせた。 その絬果は，表 1 および図 3 に示す。SA-1 を基愺にして，硝酸 添加により酸珄へヘシフトした SA-4 $(\mathrm{pH}=3.68)$ は，比表面砥は 娍少，細孔径分布はモード径の大きい万へ移怔しつつ蝠広に，見 かけ密度は㳦少，空間率は增加した。また，全試料中この场合の みアルミナ含有盘はいちじるしく娍少した。 $\mathrm{NaOH}$ 添加により フルカリ㓝ヘシフトした SA-5 ( $\mathrm{pH}=6.72)$ は比表面穔はあまり 变わっていないか，細孔径分布は小モード径側へ移動した。見か

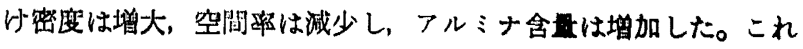

7) R. C. Merrill, R.W. Spencer, J. Phys. Colloid Chem., 54, 806(1950). 
らのことから， pH の影整として， pH 4.5 で得られたシリカア ルミナゲルをより酸性側にするとゲル粒子の増大が，反刘にアル カリ侧にすると微小化が起こることがわかる。

SA-1 ゲルのゲル化完了時（pH 4.5）にはかなり粒子径の揃っ た粒子から棈成されているとはいえ，粒子径は完全には揃っては いない。これらの粒子のうち，幾分であ小さい粒子は低 $\mathrm{pH}$ 侧で はとくに $\mathrm{Al}^{3+}$ の溶解性に富み ${ }^{81}$, 溶出 $\mathrm{Al}$ イオンは大粒子表面に 析出するといら Ostwald 就成 ${ }^{9}$ が進行する。よって, SA-4 では 構成粒子の大粒子化が起こり，比表面程の減少，細孔径の增大と いう結果となったと考えられる。また，低 $\mathrm{pH}$ の溶液中にはかな りの $\mathrm{Al}^{3+}$ が溶存しているため, 収得ゲル中のアルミナ含有量は 減少すると考えられる。

一方， SA-5 のよ5に $\mathrm{pH}$ を 4.5 から中性付近 $(\mathrm{pH}=6.72)$ にした場合, シリカの溶解度は $\mathrm{pH}=4.5$ とくらべてあまり变わ らない(10)。アルミナ含最がもっとも大きい值となっていることか ら, $\mathrm{pH}=4.5$ で夜相に残っていた $\mathrm{Al}^{3+}$ が $\mathrm{Al}(\mathrm{OH})_{3}$ の微細粒子 として析出したるのと考えられる。 $\mathrm{Al}(\mathrm{OH})$, の析出は, $\mathrm{pH}$ が 5 から8の間で顕著礼でありこれがすでに固相をなしているシリ カアルミナゲルのゲル粒子間で起こるため細孔径は小さい側にシ フトしたるのと推考される。また，アルミナ含有率は $\mathrm{pH}$ の增加 でッリカの溶出が起こり增加したと考えられる。

SA-1 から 7 のアルミナ含量について, SA-4 を除くすべての 試料は計画した量論値のアルミナ $25 \mathrm{wt} \%$ よりも高い $30 \mathrm{wt} \%$ 以上の值を示した。これは $\mathrm{pH}=4.5$ でのコロイド状シリカの溶 解度の高さ ${ }^{111}$ にるるのと教えられる。

\section{2 固体酸是之触媒活性}

収得ゲルの测定固体酸量 $A_{\mathrm{a}}$ を強度別に表 2 に示した。各試料 の酸㨁に違いが喼められる。このような差異をすたらするのとし て, 第一にゲル構成粒子内部のシリカとフルミナの組成ならびに それらの原子オーダーの混合度が，第二に緗孔構造がある。後者 に関しては，固体酸昷が Hammett 指示楽の变色を目安にブチル
Table 2 Solid acid amounts

\begin{tabular}{|c|c|c|c|}
\hline \multirow[b]{2}{*}{ Sample } & \multicolumn{3}{|c|}{$A_{\mathrm{a}}(\mathrm{mmol} / \mathrm{g})$} \\
\hline & $\begin{aligned} &+3.3 \geqq H_{0} \\
& \geqq-3.0\end{aligned}$ & $-3.0 \geqq H_{0}$ & $-5.6 \geqq H_{0}$ \\
\hline SA-1 & 0.045 & 0.084 & 0.141 \\
\hline $\mathrm{SA}-2$ & 0.077 & 0.038 & 0.210 \\
\hline $\mathrm{SA}-3$ & 0.019 & 0.104 & 0.042 \\
\hline $\mathrm{SA}-4$ & 0.116 & 0.017 & 0.152 \\
\hline SA-5 & 0.084 & 0.058 & 0.068 \\
\hline SA-6 & 0.059 & 0.061 & 0.195 \\
\hline SA-7 & 0.073 & 0.062 & 0.200 \\
\hline
\end{tabular}

アミンの滴定により測定されるので, 原理的には指示薬およびア ミンが溶媒で湍たされたゲル細孔内に拻教できるかどうかで，固 体酸测定量が変わると考えられる。しかし，細孔檏造の湘定媒体 である窒素分子とブチルフミンの間にそれほど大きな吸着占有面 積の差異はないと考え，ここでは問題にしない。したがって，表 2 に示した固体酸盟は調隻条件を反映した表面化学組成による装 面特性であると考党られる。

反応は，ゲルの細孔に基づく拆散抵抗を無視できる粒径（多孔 钼蚛媒粒度 $147 \mu \mathrm{m}(100$ メッシュ-under)) を予借実験で確認し てから行なったので，真の活性（細孔内拡散に基づく触媒有效係

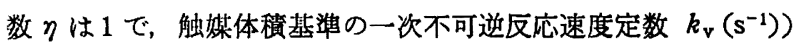
と考えられる。裴 3 に実測の真の反応速度定数ならびに 1-ブテ ン翼珄化反応に上る初期生成物の cis-扰よび trans-2-ブテンの比 (cis/trans 比) を示した。

本棒験での cis/trans 比はほぼ 1 であった。 cis/trans 比の值が 1 のとき，その反応は Br $\phi$ nsted 酸点上で進行することが, 1-メ チルプロピルカチオン中間体の確認 ${ }^{12}$ によって襄付られている。 また, Lewis 酸のみをるつとされているフッ化アンモニウム処理 アルミナ上では, $\mathrm{H}^{-}$の引き抜きによる1-メチルフリルカチオン を経由して進みこの比が約 2 であると確認13)されている。よっ

Table 3 Catalytic activity

\begin{tabular}{|c|c|c|c|c|c|c|}
\hline \multirow{2}{*}{ Sample } & \multirow{2}{*}{$\begin{array}{c}\text { Apparent } \\
\text { acid amount } \\
A_{\mathrm{a}} \\
\left(+3.3 \geqq H_{0}\right) \\
\left(\mathrm{mmol} \cdot \mathrm{g}^{-1}\right)\end{array}$} & \multirow{2}{*}{$\begin{array}{c}\text { Chemisorptive } \\
\text { acid amount } \\
A_{\mathrm{mc}} \\
\left(\mathrm{mmol} \cdot \mathrm{g}^{-1}\right)\end{array}$} & \multirow{2}{*}{$\begin{array}{c}\text { Acid amount } \\
\text { effective to } \\
\text { the reaction } \\
A_{v} \\
\left(\mathrm{mmol} \cdot \mathrm{cm}^{-3}\right)\end{array}$} & \multirow{2}{*}{$\begin{array}{c}\text { Intrinsic rate } \\
\text { constant }{ }^{b)} \\
k_{\mathrm{v}} \\
\left(\mathrm{s}^{-1}\right)\end{array}$} & \multicolumn{2}{|c|}{ cis/trans ratio } \\
\hline & & & & & $180^{\circ} \mathrm{C}$ & $210^{\circ} \mathrm{C}$ \\
\hline SA-1 & 0.270 & 0.055 & 0.068 & 10.81 & 1.45 & 1.20 \\
\hline SA-2 & 0.353 & 0.078 & 0.081 & 12.13 & 1.02 & 0.80 \\
\hline $\mathrm{SA}-3$ & 0.165 & 0.045 & 0.042 & 6.19 & 1.26 & 0.96 \\
\hline $\mathrm{SA}-4$ & 0.285 & 0.106 & 0.104 & 23.53 & 0.68 & 0.72 \\
\hline SA-5 & 0.210 & 0 & 0 & 0 & - & - \\
\hline SA-6 & 0.315 & 0.093 & 0.112 & 23.18 & 1.40 & 0.82 \\
\hline \multirow[t]{2}{*}{ SA-7 } & 0.335 & 0.077 & 0.094 & 19.54 & 1.15 & 0.84 \\
\hline & & & & Average & \multicolumn{2}{|c|}{1.03} \\
\hline
\end{tabular}

a) Johnson's method.

b) 1-Butene isomerization. $k_{v}$ is defined as rate constant based on the catalyst volume.

8) J. E. Singley, J. Am. Water Works Assoc., 60 (No. 11) $1280(1968)$; 佐藤莎郎, 触媒, 14( 5 ), 134(1972).

9) 後藤克己, “触媒の化学と工学”, 化学同人（化学增刊 12 号), 115(1963)；向井田煡一, “触媒工学講坐 5 (工学綱)

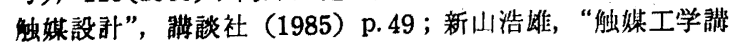
座 5 (工学編) 触媒設矿”, 塆啖社 (1985) p. 131.
10) R. K. Iler, "The Colloid Chemistry of Silica and Silicates", Cornell Univ. Press, New York (1955) p. 9.

11) R. K. Iler, "The Colloid Chemistry of Silica and Silicates", Cornell Univ. Press, New York (1955) p. 4.

12) J. W. Hightower, W. K. Hall, Chem. Eng. Prog. Symposium Series, 63, 122(1967).

13）上松敬跍, 有合化，30，874(1972). 


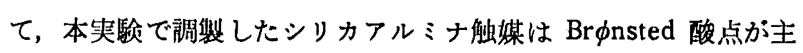
であると考兄られる。このことは，共ゲル化によるシリカアルミ ナの Lewis 酸基は Bronsted 酸量にくらべ極端に少ないとした 斯波らの報告 ${ }^{14)} と 一$ 致している。むた, アミン吸着で測定される 固体酸圔は Bronsted 酸と Lewis 酸さらに物理吸着量が含まれ るが，少量の Lewis 酸があったとしても，本实験のような低温 では Lewis 酸は気相中の水分子の吸着により Bronsted 酸に变 わっていることも拷られる。

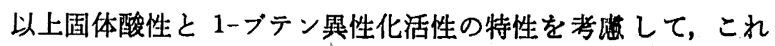
らの関係を解析した。両特性の相関を検討するにあたり，質基 淮，表面基準，体䠝其準の各值で整理を行なった。すべてにほぼ 良好な相関がみられ，その中で一番よい相関性を示したのが体栍 基準であった。また，著者らは多孔質触媒内の反応も考えていく といら立場から体稍基準を採用した。以下にその整理法を示す。

(1) まったく伤媒活性を示さなかった試料 SA-5 に着目し，そ の全固体酸量 $0.210 \mathrm{mmol} \cdot \mathrm{g}^{-1}$ をすへて物理吸着量とした。

(2) 試料 $\mathrm{i}$ ( $\mathrm{i}$ は試料 SA-1 7 の陚料番号 1 7 7示す) の 物理四着量 $A_{\mathrm{mpl}}$ を推定するために，吸着点の表面密度が七つの 試料ともほぼ等しいと考兄, 試料 SA-5 の表面密度 $A_{\mathrm{a}} 5 / S_{\mathrm{m}} 5$ と 等しいと仮定した次式で求める。

$$
\begin{aligned}
& A_{\mathrm{mpl}}=\left(A_{\mathrm{a}} 5 / S_{\mathrm{m}} 5\right) \times S_{\mathrm{ml}}=0.210 \times\left(S_{\mathrm{m} 1} / S_{\mathrm{m}} 5\right) \\
& \text { ただし }, A_{\mathrm{a}} 5=A_{\mathrm{mp}} 5
\end{aligned}
$$

したがって試料 $\mathrm{i}$ の化学吸着固体酸量 $A_{\mathrm{mcl}}\left(\mathrm{mmol} \cdot \mathrm{g}^{-1}\right)$ は, 全 固体酸䧟 $A_{\mathrm{a} 1}$ と物理吸着量 $A_{\mathrm{mpl}}$ との差

$$
A_{\mathrm{mol}}=A_{\mathrm{al}}-A_{\mathrm{mpl}}
$$

として推算し，反応に有効な強度を有する酸点の量とした。

(3) 試料 $\mathrm{i}$ の有效四着量 $A_{\mathrm{mo1}}$ に実測した見かけ密度 $\rho_{\mathrm{B}: 1}(\mathrm{~g}$ ・ $\mathrm{cm}^{-3}$ ) を乘して多孔質固体の単位体䖽あたりの有效固体酸奛 $A_{\mathrm{v} 1}$ を求めた。表 3 にこれらの値を示した。

裴 3 から，物理構造が等しいSA-1 と6 の有効固体酸量ならび に反応速度定数を比洨すると大きく違らことがわかる。混合方向 による影響は，物理棈造に関しては見られなかったが，表面特性 としての固体酸量や触媒活性には影響を与え，制御の難しさがう かがえる。括とらく、ゲル權成粒子個々の表面化学組成の迕いで あろら。

図 5 に前に述べた単位体䠝市たりの真の反応速度定数 $k_{\mathrm{v} 1}$ に対 して $A_{\mathrm{va1}}$ をプロットした。因から明らかなように雨者にはよい 相関関係が浔められた。

フルミナ含有量 $C_{\mathrm{a}}$ と化学吸着レヘルの固体酸最 $A_{\mathrm{mc}}$ の関係 を図 6 に示した。Holm らの研究 ${ }^{15)}$ によれば，共ゲル化法による シリカアルミナでは $C_{\mathrm{a}}$ が $20 \%$ 付近に固体酸量（質量基準）の 罗大值が存在するとされている。四 6 は，その傾向と部分的に一 致する結果となった。

\section{4 結 睔}

共ゲル化法によるシリカアルミナの調製に関して, 本研究で得

14）斯波忠夫，佐潦正焳，服部 英，吉田和昭，触媒，6，80 (1964).

15) V. C. F. Holm, G. C. Bailey, A. Clark, J. Phys. Chem., 63, 129(1959).

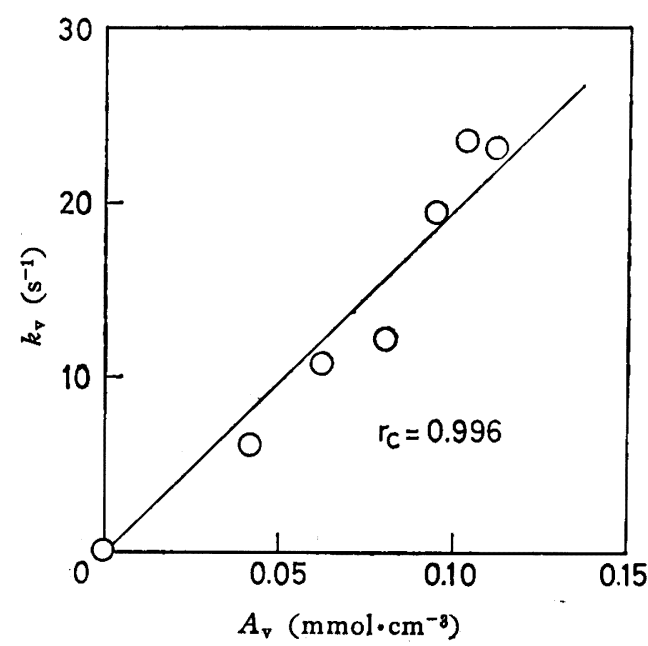

Fig. 5 Relationship between the intrinsic rate constant and the effective acid amount to the reaction for the catalysts prepared

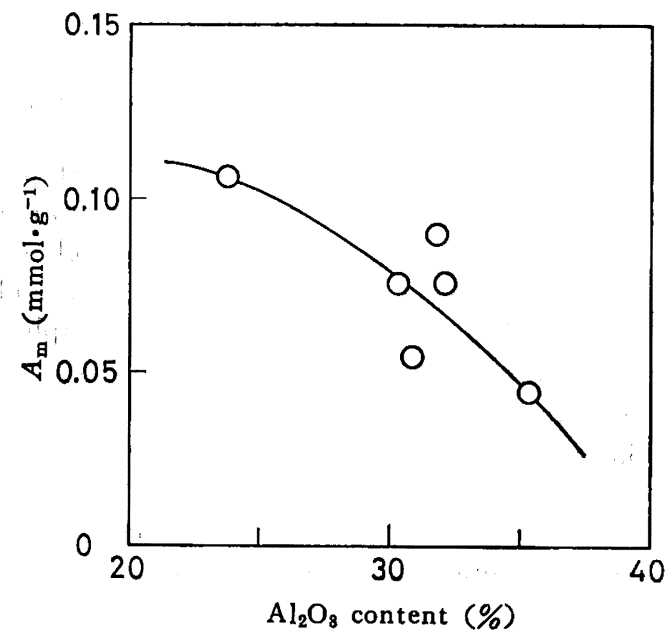

Fig. 6 Relationship between the chemisorptive acid amount and $\mathrm{Al}_{2} \mathrm{O}_{3}$ content for the catalysts prepared

られた知見はつぎのとおりである。

（1）古くからシリカアルミナ調製のゲル化反応では，混合方 向で触媒特性が與なるといわれてきた。本研究でも試料 SA-1 と 6 の比校からわかるように，ゲル化歭間以内に均一過館和溶液か 得られるならば，生成ゲル粒子は粒子径が揃ったるのとなり，平 均組成や細孔棈造はほぼ同一のものとなった。しかし，1ーブテン 哭性化活性や固体酸性などの表面特性までは同一にすることがで きないことがわかった。

（2）ゲル化時間よりも長い時間をかけてゲル化剂溶夜の注入 を行なら場合，ゲル檴成粒子は均一にならず，巨大に析出成带し たゲル粒子が生成する。同時に，系内の濃度が低下していった時 点で生成する微小粒子までを含む広い粒子径分布となる。ケイ酸 ナトリウムが硝酸フルミニウムに注入される混合方向の場合、注 入時間が長くなるにしたがい，細孔径分布のモード径が増大す る。混合方向が逆の揚合, モード径は小さくなる。しかし，何れ 
の場合も細孔径分布は，ゲル化時間よりも短い注入時間で得られ るゲル（SA-1，6）よりも幅広になる。

（3） $\mathrm{pH}$ の移動を行ならことによっても，細孔構造は大きく 変化し, $\mathrm{pH}$ が 3.68 では比表面積低下（大粒子生成）でかつ細 孔径分布はモード径が大きい方にシフトし幅広になる。固体酸量 および触媒活性はいずれも最大であった。これに対して，pH が (j)

Pore Structure, Acid Property and Catalytic Activity of Silica Alumina Gels Prepared by Various Methods

\author{
Hiroto Hirano*, Mitsuyasu Hiranuma, Ken-ichi Mukaida**
and Haruo Watanabe** \\ Hiroto Hirano*, Mitsuyasu Hiranuma, Ken-ichi Mukaida**
and Haruo Watanabe** \\ Department of Industrial Chemistry, Tomakomai National College of Technology; \\ Tomakomai-shi 059-12 Japan \\ ** Department of Chemical Engineering, Muroran Institute of Technology; \\ Muroran-shi 050 Japan
}

6.72 のとき，細孔径分布はモード径が小さくなり，鋭い分布とな

有効固体酸量（体積基準）推定値と 1-ブテン異性化反応 に打ける反応速度定数（体積基準）との間には良好な相関関係が みられた。

For the preparation of silica alumina gels by means of cogelation from the aqueous solution of sodium silicate and aluminium nitrate were examined the effects of several operational conditions on the physico chemical properties including solid acidity and catalytic activity. If the time of pouring a solution into another was shorter than the so-called gelation time, under an adequate agitation, different pouring directions didn't make any difference on the pore size distribution and the surface area of the gels. If the pouring time was longer than the gelation time, the pore size of gels distributed broadly, reflecting the broad size distribution of the gel constituent particles. This results from unsteady heterogeneous gelation. By shifting $\mathrm{pH}$ to acid after the completion of the cogelation, the particle diameter of the resultant gel increased, the alumina content decreased, the solid acid amount and the catalytic activity were enhanced. On the other hand, by shifting $\mathrm{pH}$ to alkaline, each characteristic is opposite to the acidic case. The alumina contents of all the gels prepared without shifting $\mathrm{pH}$ tend to be larger than the target. The good correlation was obtained between the intrinsic activity for 1-butene isomerization and the predicted value of the acid amount from chemical adsorption level. 